Article

\title{
Evaluation of Lifelong Learning Centers in Higher Education: A Sustainable Leadership Perspective
}

\author{
Gülşah Taşçı $1, * \mathbb{C}$ and Osman Titrek ${ }^{2}$ \\ 1 The Ministry of National Education, Kocaeli 41000, Turkey \\ 2 Educational Sciences Department, Education Faculty, Sakarya University, Hendek 54300, Sakarya, Turkey; \\ otitrek@sakarya.edu.tr \\ * Correspondence: gulsahtasci@yahoo.com
}

Received: 14 September 2019; Accepted: 11 December 2019; Published: 18 December 2019

\begin{abstract}
Technological developments that have taken place in the 21st century have also affected higher education institutions. These changes have created an obligation to respond to the effects and needs of globalization. In response to these developments, the emphasis on lifelong learning and individuals who "learn how to learn" in higher education institutions has become more and more important in order to educate individuals to fulfill the needs of the century. In general, studies on topics such as the development of lifelong learning in higher education and the role of leaders are limited in Turkey. Regarding this point of view, the current study aims at examining the perceptions of sustainability leaders studying in the higher education sector in Turkey in terms of the lifelong learning provided, the strategies applied, the difficulties faced, the experiences shared, and the sustainability practiced. Therefore, the study uses a descriptive phenomenological pattern under a qualitative research method. The study group was established with maximum diversity, using a purposeful sampling technique. The study group consisted of 10 middle-level managers working at the universities in the Marmara region. The topic was discussed with the study group members in depth. In this study, the data were collected with a semi-structured interview form created by the researchers. In the analysis of data, a content analysis method was used. As a result of the research, it was found out about those observed that administrators in higher education institutions define lifelong learning in a similar way to the definitions in the literature. In addition, the strategies of administrators for lifelong learning, their views concerning their experiences, and their views on the difficulties they encountered are revealed in the research. In the last part, practical recommendations suggestions are made using with regard to the results of the research.
\end{abstract}

Keywords: lifelong learning; higher education; sustainable leadership; Turkey

\section{Introduction}

In recent years, major universities, governments, and non-governmental organizations around the world have been in continuing discussions on the practice of lifelong learning. Technological developments that have occurred in the 21st century have also affected higher education institutions, and this has led to changes, developments, and an obligation to respond to the effects and needs of globalization. In response to these developments, with the emphasis placed on lifelong learning in higher education institutions and on the individual who "learns how to learn", it has become more and more important to educate individuals to meet the needs of the century. Given that learning is a lifelong process, in other words, a process of continuous self-improvement of the individual, it is very important from the individual's perspective to respond to the pace of science and technology. The institutions that are intermediary to this development are higher education institutions. Especially 
in recent years, with the Bologna Declaration, awareness has been created within the scope of lifelong learning and important contributions have been made to realize the concept [1].

The statement "The illiterate of the 21st century will not be those who cannot read and write, but those who cannot learn, unlearn, and relearn" as shown in Alvin Toffler's work "Rethinking the Future" [2] and which has become one of the slogans of the century, is an important determination in terms of both the individual and the social satisfaction of individuals as individuals who are able to keep up with the times. Furthermore, the concept of lifelong learning has emerged in order to adapt to rapidly evolving and changing social and cultural life and has become an important indicator of the level of education and employment conditions in developed and developing countries [2] (p. 3). The transition of universities to mass education today, in other words, giving the necessary importance to lifelong education, is among the agenda topics of higher education. Thus, the university has emerged as a major player among potential providers of lifelong learning.

When the literature is examined, it is revealed that there are numerous indicators that lifelong learning should adopt as a strategy. There are certain numbers of studies carried out regarding lifelong learning [3-7], especially among European countries. Studies regarding the topic have been increasing gradually in recent years in Turkey [8-12]. In particular, it can be said that lifelong learning studies [13-15], in which the importance of higher education is emphasized, have increased in the literature especially with the Bologna Declaration. In parallel to these developments, Titrek, Zafer Güneş, and Sezen [16] proposed a model for lifelong learning in higher education in Turkey. In addition, Dindar and Bayrakçı [17] examined the factors that affect students' lifelong learning in higher education. On the other hand, when the literature is examined, it is apparent that there have been studies on sustainable leadership conducted in this area [18-38]. However, neither studies regarding the development of lifelong learning in higher education in Turkey nor the role of sustainable leaders have been approved by the current literature.

Higher education institutions, which kept up with the change and transformation, have been raising sustainable leaders throughout the years. In this respect, one of the key points in higher education institutions is sustainable leadership strategies that must take the core values and stability of the organization into account [31]. Sustainability is more than a trendy concept, and it is about implementing a resilient culture for continuous development [38]. Higher education institutions, in particular, are in need of sustainable leadership to develop sustainable institutions. Thus, the key to sustainability in higher education institutions seems to be in line with leadership skills and perspectives. Sustainable leadership of universities requires the adoption and integration of new management style trends to facilitate human resource development and to provide a working environment both for employees and for student satisfaction and to draw them towards the achievement of institutional goals and objectives [39].

It is, therefore, also important to explain the role of leaders in higher education qualitatively. The basis of this work is constituted by the general philosophy of lifelong learning and the sustainable leadership theory of Lambert [33]. For this reason, this study focuses not only on examining the views of administrators at lifelong learning centers in universities in Turkey regarding their perception, strategy, and experience in lifelong learning but also on what kinds of sustainable leadership behavior would ensure effective implementation of lifelong learning studies in higher education. This research is therefore important in describing the role of leaders in higher education qualitatively. It is focused on examining the views of perceptions, strategies, and experiences of executives in higher education in Turkey regarding lifelong learning and sustainable leadership. For this reason, the answers to the following questions were sought in the study:

(1) What is the meaning of lifelong learning according to lifelong learning center administrators in higher education?

(2) How are the strategies of lifelong learning center administrators in higher education implemented?

(3) According to lifelong learning center managers in higher education, how do they face difficulties in lifelong learning practices in their universities? 
(4) What kinds of sustainable leadership behavior will effectively implement lifelong learning activities according to lifelong learning center administrators in higher education?

\section{Literature Review}

\subsection{Lifelong Learning Concepts}

Life-long and life-wide learning concepts, which emphasize the need to renew existing knowledge, skills, and abilities in line with the conditions of today's information and technology age, have become an important requirement. Lifelong learning, as a concept, is not new, because lifelong learning was mentioned in Yeaxlee's book "Lifelong Education", published in 1929 [40]. As can be seen, although the concept of lifelong learning has been in the literature for years, this idea was drawn attention to widely by the Council of Europe in the late 1960s and early 1970s [40] (p. 1). The term lifelong learning has become a central tenet of European education policy since the late 1980s. This term was drawn on in the Grundtvigian model inspired by public universities [41]. UNESCO has defended the principles of individual development of the Delors Report. On the other hand, the economic effects of the EU and OECD and the economic objectives related to lifelong learning have been the subject of critical criticism [42].

Lifelong learning can be defined as simply increasing the knowledge and skills of individuals throughout their lives for economic or personal development through formal or informal learning opportunities [43]. Lifelong learning is the life-long learning activities that we encounter in a formal, widespread, perceptual manner from birth to death [44]. Lifelong learning is an approach that covers the knowledge, skills, and attitudes of people and all the personal, social, and employment-related learning activities they perform throughout their life [45]. There are many definitions of lifelong learning that have a common idea that learning is a process. Lifelong learning has been described by some in generally humanistic terms as a way of empowering people for active participation in important personal, social, and global issues. Others adopt a narrower instrumental approach that prioritizes the acquisition of skills and qualifications to enhance economic competitiveness and productivity [46]. Predictions about lifelong learning have gained importance, especially in light of current predictions that by 2050, 9.2 billion people will live in the world, and, in this context, everyone will need to constantly train themselves to increase their employment chances. The information explosion will conclude that many people will have no time to read, hear, see, investigate, and learn everything [47].

The aim of lifelong learning is to provide opportunity for individuals who are able to participate actively in all areas of life regardless of age, gender, social, and economic status to be involved in society [48] (p. 35), and to develop themselves at an individual level personally, professionally, and intellectually [49], while it is regarded as an opportunity for individuals to keep their knowledge up-to-date at all times [50] (p. 100), as well as a process that helps to maintain a better quality of life in terms of a wider democracy that encompasses the whole of society and prepares them for a more valuable life to be offered to individuals [51] (p. 220). Given that learning is a lifelong process, in other words, the continuous self-improvement of the individual is very important in terms of being able to respond to the pace of science and technology.

\subsection{Lifelong Learning Center in Turkey}

When the concept of lifelong learning is examined from the perspective of Turkey, it is seen that it has a long history [52]. Among these aforementioned institutions, village institutes have great importance and contribution. In later years, the village institutes were transformed into the General Directorate of Public Education and then the General Directorate of Apprenticeship and Non-Formal Education, and with the enactment of the Basic Law on National Education, it was named as formal and widespread in the education system. Eventually, it took its final form when the General Directorate of Lifelong Learning came into operation in 2011 [53]. 
When taken from the point of view of higher education institutions, it is seen that many universities organize various educational activities within this scope. Lifelong learning is one of the aims of lifelong education centers, which have an important place among the units of universities providing services for the society [54]. Especially in the report "Turkey's higher education strategy", which reflects the lifelong learning strategy of universities published by YÖK (The Council of Higher Education) [55], the dissemination of lifelong learning has been one of the main objectives.

Lifelong learning is a form of social behavior; it is a continuous process, and education improves personal and social relationships as well as social and personal preferences. Universities can be understood as creators and designers of the culture of lifelong learning in society [15] (p. 185). Lifelong learning is a key theme in the current education debate and is focused on the need to think about the role of higher education and universities in contemporary society [56] (p. 531). Provided that universities are more dynamic and inclusive organisms that can promote more accessible and lifelong learning, they can play an active role in the growth processes of society and professions and actively contribute to the development of business policies in general. It is in this particular context that the theme of learning and recognition of experience needs to be placed [57] (p. 42).

Apart from these activities, which can be seen as activities aimed at lifelong learning, there are units established within the structure of universities and which are directly oriented to the society with various educational services in Turkey: universities, practice research centers, continuing education centers, and language practice research centers in the form of units with the knowledge they have for the benefit of the community and transfer efforts. With the determination of Imanov [58], these centers are established depending on the administrative structure, rectorate, dean, and departments. Lifelong learning centers operate under the rectorate in administrative structure maintenance. The structure and functioning of lifelong learning centers in universities were established in accordance with the Higher Education Law No. 2547, which aims to meet the educational needs of society and help the development of the society by organizing educational programs that provide knowledge and skills to individuals [59]. However, during this process, managers of lifelong learning centers in universities face various problems in the implementation phase. In this context, the opinions of the executives, who play an important role in lifelong learning, are needed.

\subsection{The Role of Lifelong Learning for Sustainable Leadership in Higher Education}

In this role of universities, their leadership approaches have a great impact. As Devlin [60] notes, "The context in which university education currently operates requires strong leadership and intelligent management." From past to present, various leadership theories have been proposed [61]. Although there are common grounds in leadership definitions, they contain different meanings. Some researchers focused their research on a leader's personal, physical characteristics, and behavior, while others focused on the relationships between the leader and the audience, while other researchers present which situations influence the leader's actions [62] (p. 6). In other words, it is observed that different kinds of leaders have emerged according to every period, place, situation, time, and circumstances in the historical process of humanity [63] (p. 2). For example, "great human" leadership theories try to understand what an effective leader is doing [64]. Also, McClelland [65] explains with motives that a leader needs power or charisma, while Bass [66] explains leadership based on transformational leadership style. On the other hand, more recent approaches seek to understand particularly relational aspects in the leader's interaction with others [67]. As a matter of fact, it is understood that there is little to define the characteristics of effective leadership [68,69].

Besides, it is also seen that there are fewer studies conducted on sustainable leadership, which has emerged in recent years. Sustainable leadership is a new concept that emerged in the 2000s [31]. Learning and leadership constitute the first principle of sustainable leadership, and it is the essence of sustainable leadership and educational change [27]. Higher education institutions, in particular, are in need of sustainable leadership to develop sustainable institutions. Thus, the key to sustainability in higher education institutions seems to be in line with leadership skills and perspectives. 
Sustainability increases the financial resistance of institutions. Among other things, it makes a significant contribution to cost-saving and efficiency agendas, helps universities manage risks (such as those related to supply chains and global partnerships), and enables universities to grow and compete sustainably. Sustainability is closely related to the core elements of effective governance in higher education [30]. Although it is not clear whether the majority of higher education institutions will lead a transformation, the number of sustainability-oriented leadership examples is growing each passing day [70].

On the other side, when developing a business strategy that incorporates sustainability principles, one of the most important obstacles that sustainable leaders must overcome is how to plan their short-and long-term futures. Adopting a sustainable approach requires a much longer time frame and perspective than the short-and medium-term planning horizon used by most leaders. On the other hand, for a higher education institution to achieve sustainable performance, there are at least three critical success factors that it must fulfill. These are leadership and vision, flexibility for change, and openness for participation [70].

Higher education institutions, in particular, are in need of sustainable leadership to develop sustainable institutions. Thus, the key to sustainability in higher education institutions seems to be in line with leadership skills and perspectives. The studies conducted with sustainability reveal that institutions with sustainable leadership have a system approach, have collaboration across borders, and problem-solving skills. It underlines that a leader needs to understand the organizational ecosystem to sustain his or her university. Thus, sustainable leaders seek to manage not just organizational change but to take guidance from seven principles as they develop higher education [38].

The first principle encourages sustainable leaders and members of higher education. The second principle emphasizes mentoring. The third principle of sustainable leadership focuses on deploying leadership and building a sense of mutual responsibility throughout the team, which allows for joint decision-making and a shift away from individual controls. The fourth principle emphasizes the protection of resources. Therefore, sustainable leadership systems can be maintained and developed when dealing with their leaders and allow leaders to look after themselves and the system. The sixth principle values diversity and develops different types of excellence in learning, teaching, and leadership, rather than applying standardized templates to everyone. The core principle of sustainable leadership focuses on innovation and resilience through its own power. Due to the multidimensional nature of sustainable leadership, higher education leaders should be aware of these seven principles when engaging assertively with local campus environments.

On the other hand, in higher education, sustainability involves a wide variety of disciplines. The Sustainable Development Goals emphasize that all students must acquire the knowledge and skills needed to promote sustainable development by 2030 [12]. As a concept, lifelong learning leads to the realization of learning as a sustainable process, because according to lifelong learning, learning never stops. Therefore, universities can no longer be considered as places specifically designed to tell and transfer knowledge to younger generations; instead, universities should ensure that people, whose ages, social and professional conditions differ from those of standard students, have the necessary tools to meet first-class quality education requirements that make a difference when it comes to professional, personal, and civil opportunities [57] (p. 42).

A sustainable leader incorporates leadership characteristics that have a specific vision for sustainability in an organization and the values associated with it. Sustainable leadership, which begins with the characteristics of the individual, expresses an understanding that these characteristics extend to broader levels, including organizations and society [71] (p. 32). In other words, sustainable leaders are the individuals who manage the harmony of the relationship between economic, social, and environmental spheres [72] (p. 67). Therefore, a sustainable leader brings people together and creates opportunities for them to explore, learn, design, and solve actions to address sustainability issues [73] (p. 31). 
Sustainable leadership affects four factors: individual, team, organization, and community. In order to become a sustainable leader, one has to start at an individual level. In that sense, self-awareness is important to the leader. Also, sustainable leaders are individuals who see and understand the social, cultural, economic, and environmental problems of their time and draw visions to the individuals who are around them with their concerns and organize them. Sustainable leaders are individuals endowed with strong values and extraordinary abilities. These individuals can accurately read the complex problems they face, solve these problems and predict the effects they will create in the future. Therefore, they have an interdisciplinary understanding and an innovative long-term perspective. Being aware of what an individual can accomplish alone, they, therefore, support teamwork, the multiplier effect of differences together, and thus the raising of individuals, and in doing so, their main goal is to build a sustainable world. Burns et al. point out that leadership for sustainability builds on but goes beyond transformational leadership. The kind of leadership required "could also be termed as "facilitation" or "caring", as the core goal is to guide people and organizations to collaboratively create visions and take action for a more sustainable and resilient world" [74] (p. 90). Also, leadership for sustainability means leading with people rather than leading people" [74] (p. 92)

The concept of sustainable leadership in education has been analyzed by scholars such as Hargreaves and Fink [24], Hoyle and Wallace [28], Fullan [23], Bottery [20], and Lambert [33,34]. According to Lambert [44], sustainable leadership in the education sector is at its beginning. Hargreaves and Fink [24] have developed a sustainable leadership model, particularly in the primary, secondary, and post-secondary education sectors. The model consists of seven dimensions, which include considerations as length, depth, fairness, width, resourcefulness, diversity, and conservation [24].

Hagreaves and Fink [24] addressed the definition of sustainability, leadership, and its seven principles. Hargreaves and Fink [24] also stated that developing an organization that incorporates sustainable leadership ideas would continue, not in the short term but in the long term, regardless of who occupies the directorship of the organization's trajectory. According to them, a sustainable leader creates an educational environment with organizational diversity and stands out as an activist who promotes the sharing and development of good and successful different ideas within society [24] (p. 3).

In 2009, Hargreaves developed his own model [27]. These are about sustainable leadership being an activist and joining the community. Davies [22] also developed a model for sustainable leadership. Svensson and Wood [37], on the other hand, identified the sustainability elements of the leader in the effectiveness of organizational performance in their work. In the research of Quinn and Dalton [36], they aimed to reveal the ways in which leaders exhibit the tasks they must perform. As a result of their work, they demonstrated that the leaders have adopted sustainability experiences like other influential leaders and that the leaders have additional capabilities as well as data collected by the interviewing method. Lambert [33], reviewing sustainable leadership models, developed an appropriate model for the college of further education. Lambert, as a result of his study, emphasized that the development of sustainable leadership would be effective in developing the skills needed for individuals in higher-level roles. Similarly, Lambert [34] has established a sustainable leadership framework in the education sector consisting of six factors including human capacity, strategy and partnership building, developing long-term goals from short-term goals, diversified workplace building, and courses. In another study, Šimanskienè and Župerkienè [35] revealed the differences between sustainable leadership and non-sustainable leadership.

\section{Methods}

This research was conducted with a phenomenology pattern from qualitative research methods. Phenomenology, on the other hand, is the identification of a phenomenon according to the experiences of an individual or group [75].

In this study, descriptive phenomenology was used to describe people's perceptions and experiences. In the study, descriptive phenomenology was used to illustrate the perceptions, strategies, and experiences of academic leaders in higher education about lifelong learning. In this research, 
the purposeful sampling method was employed. According to Patton [76], the logic and power of purposeful sampling come from its emphasis on in-depth understanding, allowing for an in-depth study of situations where purposeful sampling is thought to contain rich knowledge. Since the phenomenological pattern was used in the study [77], a limited number of academic leaders, who experienced the phenomenon and could explain it, were interviewed in detail in order for the data collected to be detailed and in-depth. Among the mid-level executives working in the universities in the Marmara region, 10 executives were selected. In the selection of continuing education centers of these universities, transportation, economy, and time were taken into account. In addition, these universities have been selected because their continuing education centers are the most effective places for practice. The characteristics of higher education executives who constitute the participants of the research were revealed. Executives were selected through the maximum sampling method. The participants' departments are education, business administration, law, and medicine, where they are mid-level executives. Their years of seniority varied between 10 and 15 years.

The study group consisted of 8 male and 2 female executives; executives in age groups; as members of the Marmara region, based on the institution they serve, there were 10 executives who work under the name of lifelong learning or continuing education centers of universities. In the research, the semi-structured interview form was used to understand the perceptions of academic leaders in higher education about lifelong learning and their views on the strategies and experiences they apply. An expert opinion was applied for the scope and appearance validity of the interview form developed by the researchers, and projected changes were made on the form. Then, after reviewing the questions in terms of language, a pilot application was also made to test the intelligibility of the interview form. The data were collected between April-October 2019. Firstly, the interviews completed in about $20 \mathrm{~min}$. Secondly, because the findings on the last question remain superficial, a second interview was conducted with the same administrators with the same questions for more in-depth discussion. In the semi-structured face-to-face interviews in the second interview, interview questions were created using Lambert's [33] theory. To discuss in more depth, especially the last question in the initial findings, a second interview was held with the same managers by making appointments. At the end of the second interview, it was seen that the research was useful in the phase of further elaboration. It was observed that the second interview ranged from about $25 \mathrm{~min}$ to $40 \mathrm{~min}$. The data of the second interview was analyzed using the content analysis method. At the end of the second interview, it was found to be useful in the process of revealing the research in more detail and analyzing it within the framework of the theory. This research was also conducted through content analysis in four stages in the form of coding the data obtained, finding the themes, arranging the codes and themes, and identifying and interpreting the findings. With content analysis, data was first read, and then important codes and dimensions were determined. By organizing the obtained codes, sub-themes, and themes, the findings were defined and interpreted.

Research data has been analyzed in accordance with categorical analysis techniques from content analysis types. Participants were coded in the form of P1-P2. In direct quotations, participant symbols were added to the end of the sentence. The coding of the data was carried out by the two researchers and then their comparisons were made. Their reliability calculations were made according to Miles and Huberman's inter-coder reliability formula [77]. As a result of the reliability analysis, the match rate was calculated as $86 \%$. In this research, which adopted a qualitative research approach, data collected from the perspective of persuasiveness, transferability, consistency, and verifiability [78] were submitted to the participants' review and necessary corrections were made by obtaining participant confirmation. Statements that the participants did not want to be evaluated were removed from the interview text.

In order to strengthen the credibility of the research, a higher education leader was interviewed again to see whether the findings were meaningful and reflected the existing situation. 


\section{Findings and Results}

In this study, the perceptions, strategies, and experiences of executives working in higher education in Turkey about lifelong learning and sustainable leadership, their views on the strategies they implemented, their views on their experience, and the challenges they face, were examined.

\subsection{Round 1}

The results of the first round of face-to-face interviews with managers at the lifelong learning center are as follows: Firstly, according to the views of the executives who work in higher education, their views on the meaning of lifelong learning were gathered under a sub-theme, "the learning process". (Table 1).

Table 1. Themes, sub-themes and codes related to the meaning of lifelong learning according to the views of executives working in higher education.

\begin{tabular}{|c|c|c|c|}
\hline Main Theme & Sub-Theme & Codes & Descriptions \\
\hline \multirow{7}{*}{$\begin{array}{l}\text { Meaning of } \\
\text { Lifelong } \\
\text { Learning }\end{array}$} & \multirow{6}{*}{$\begin{array}{l}\text { Learning } \\
\text { process }\end{array}$} & $\begin{array}{l}\text { The process of } \\
\text { learning from } \\
\text { birth to death }\end{array}$ & $\begin{array}{l}\text { Lifelong learning is a process that continues from the beginning of } \\
\text { human life to death (P3). } \\
\text { Learning from cradle to grave (P1). } \\
\text { Learning to learn until the end of an individual's life (P9). }\end{array}$ \\
\hline & & $\begin{array}{l}\text { Education covers } \\
\text { the whole life }\end{array}$ & $\begin{array}{l}\text { It is the spread of education to the whole life of the individual (P2). } \\
\text { It is the reflection of a planned or unplanned learning process in } \\
\text { every moment of life (P3) }\end{array}$ \\
\hline & & $\begin{array}{l}\text { Age-time-space } \\
\text { to be unlimited }\end{array}$ & $\begin{array}{l}\text { It is unlimited education where education is not limited by age and } \\
\text { time (P4). } \\
\text { Formal, non-formal education (P7). }\end{array}$ \\
\hline & & $\begin{array}{l}\text { Access to change } \\
\text { and speed of } \\
\text { information }\end{array}$ & $\begin{array}{l}\text { It is the formal and informal continuation of learning in order to } \\
\text { reach the changing life conditions and speed of knowledge (P8). } \\
\text { Not lagging behind knowledge and technology is continuous } \\
\text { self-improvement (P10). } \\
\text { It is the continuation of the individual's learning process in order to } \\
\text { keep pace with development and change (P5) }\end{array}$ \\
\hline & & $\begin{array}{c}\text { Education } \\
\text { philosophy for all }\end{array}$ & $\begin{array}{l}\text { Everyone needs to see lifelong learning as an educational } \\
\text { philosophy. Lifelong learning is an educational philosophy, a view } \\
\text { of life (P6). }\end{array}$ \\
\hline & & $\begin{array}{l}\text { Individual, social, } \\
\text { and economic } \\
\text { development }\end{array}$ & $\begin{array}{l}\text { Lifelong learning is primarily the process of developing an } \\
\text { individual, then contributing to society and contributing to } \\
\text { economic development. This triangle is interconnected (P1). }\end{array}$ \\
\hline & & $\begin{array}{l}\text { Development of } \\
\text { skills }\end{array}$ & Improving the abilities of individuals in line with their interests (P2). \\
\hline
\end{tabular}

The results of the first round of face-to-face interviews with managers at the lifelong learning center are as follows and firstly, when the views on the meaning of lifelong learning according to the views of the managers working in higher education were examined in the study, it was seen that leaders see lifelong learning as a learning process that contributes to personal development. The process of learning from birth to death is expressed as the process of education covering all life, age-space-time being unlimited, access to the pace of change and knowledge, and the development of abilities and learning processes. As a result of this study, the finding that the executives (leaders) of the institutions have a high level of awareness about lifelong learning is supported. On the other hand, when the definitions related to lifelong learning are examined, it is seen that the definitions overlap with the definitions made in the literature.

Secondly, the views of the academic executives working in higher education regarding the strategies they have implemented for lifelong learning have been gathered under two sub-themes: institutional strategies and inter-institutional strategies (Table 2). 
Table 2. Themes, sub-themes and codes related to strategies implemented by executives in higher education for lifelong learning.

\begin{tabular}{|c|c|c|c|}
\hline Main Theme & Sub-Theme & Codes & Descriptions \\
\hline \multirow{5}{*}{ Strategies } & \multirow{4}{*}{$\begin{array}{l}\text { Institutional } \\
\text { Strategies }\end{array}$} & $\begin{array}{l}\text { Access-increasing the } \\
\text { number of adult } \\
\text { students }\end{array}$ & $\begin{array}{l}\text { We use social media effectively to increase their numbers in } \\
\text { adult education (P3-P4). }\end{array}$ \\
\hline & & $\begin{array}{l}\text { Setting clear goals } \\
\text { and vision }\end{array}$ & $\begin{array}{l}\text { We determine strategies according to the needs of the society } \\
\text { at the university (P9). }\end{array}$ \\
\hline & & $\begin{array}{l}\text { Focus on } \\
\text { needs-oriented } \\
\text { applications }\end{array}$ & $\begin{array}{l}\text { Game therapy instructor training (P1-P10). } \\
\text { Tales of narrative therapy instructor training (P2-P3). } \\
\text { Robotic coding educator training (P7-P4-P5) }\end{array}$ \\
\hline & & $\begin{array}{l}\text { Including trainings to } \\
\text { improve academics } \\
\text { and professional } \\
\text { development }\end{array}$ & $\begin{array}{l}\text { English is one of the first preferred training } \\
\text { (P1-P2-P3-P4-P5-P7-P10). } \\
\text { Academic article writing training, SPSS training are given to } \\
\text { academicians (P1-P2-P3). } \\
\text { Time management, communication skills (P9-P6-P8). }\end{array}$ \\
\hline & $\begin{array}{l}\text { Inter- } \\
\text { institutional } \\
\text { Strategies }\end{array}$ & $\begin{array}{l}\text { Cooperation with } \\
\text { non-governmental } \\
\text { organizations (such } \\
\text { as certificate } \\
\text { programs) }\end{array}$ & $\begin{array}{l}\text { We cooperate with trade unions, especially for teachers, STEM } \\
\text { and so on. We opened courses in the fields this year (P1). } \\
\text { We carry out joint studies with public education centers (P9). } \\
\text { We cooperated with the X union. Mediator training, mediation } \\
\text { training (P8). } \\
\text { We have collaborations in fields such as BOTAŞ and } \\
\text { Automotive sector. We provide trainings (engineers, } \\
\text { technicians) (P7). }\end{array}$ \\
\hline
\end{tabular}

The views of the executives working in higher education regarding the strategies they have implemented for lifelong learning have been gathered under two sub-themes as institutional strategies and inter-institutional strategies. Institutional strategies have been stated as "access-increasing the number of adult students, setting clear goals and vision, focusing on need-oriented applications, and providing training to develop academics. The inter-institutional strategy has been expressed as co-operation with non-governmental organizations (such as certificate programs).

Thirdly, the difficulties experienced in practices of executives in higher education related to lifelong learning in universities are gathered under four sub-themes: academic, economic, technical and hardware difficulties, and problems with non-governmental organizations (Table 3).

Table 3. Themes, sub-themes and codes related to the difficulties experienced by executives in higher education in lifelong learning practices.

\begin{tabular}{|c|c|c|c|}
\hline Main Theme & Sub-Theme & Codes & Descriptions \\
\hline \multirow{4}{*}{$\begin{array}{l}\text { Difficulties in } \\
\text { implementation }\end{array}$} & \multirow{4}{*}{ Challenges } & $\begin{array}{l}\text { Economic } \\
\text { Challenges }\end{array}$ & $\begin{array}{l}\text { We have many projects on lifelong learning. However, it limits } \\
\text { what we want to provide inadequate funding (P4). } \\
\text { From time to time, the number of students who do not have } \\
\text { enough financial budget affects those who want to attend the } \\
\text { course in the lifelong learning center (P6). }\end{array}$ \\
\hline & & $\begin{array}{l}\text { Academic } \\
\text { Challenges }\end{array}$ & $\begin{array}{l}\text { In the courses, people's expectations can be at different levels (P1). } \\
\text { We sometimes have trouble with this situation (P3). } \\
\text { The perspectives of the students and their high motivation, that is, } \\
\text { their willingness to learn, affect the quality of education (P8). }\end{array}$ \\
\hline & & $\begin{array}{l}\text { Technical and } \\
\text { Hardware } \\
\text { Challenges }\end{array}$ & $\begin{array}{l}\text { From time to time, we experience difficulties with the lack of staff } \\
\text { and equipment (P4-P5). } \\
\text { There may be technical hardware problems. For example; When } \\
\text { we work with inadequately equipped people who will be given } \\
\text { game training, we cannot receive positive feedback (P10). } \\
\text { When we provided robotic coding training in a laboratory with } \\
\text { insufficient equipment and equipment, we experienced various } \\
\text { problems. Therefore, well-equipped physical environments are } \\
\text { very important in lifelong learning (P7-P9). }\end{array}$ \\
\hline & & $\begin{array}{l}\text { Challenges with } \\
\text { Civil Society } \\
\text { Organizations }\end{array}$ & $\begin{array}{l}\text { We want to cooperate with NGOs. However, we have problems } \\
\text { such as disagreement in mutual agreements and disagreement in } \\
\text { financial matters (P2). }\end{array}$ \\
\hline
\end{tabular}


The difficulties experienced by executives in higher education related to Lifelong Learning were seen to emerge under four sub-themes: academic, economic, technical and hardware difficulties, and problems with non-governmental organizations. Managers of continuing education centers in Turkey seem to face problems particularly and primarily related to economic difficulties. In order to overcome these difficulties, higher education policies should be regulated, and solutions should be produced within the local context.

Fourthly, the views of higher education executives regarding the sustainable leadership behaviors they exhibit towards lifelong learning are gathered under a sub-theme of sustainable leadership. Under this sub-theme, the codes "exhibiting transformational-transformative characteristics", "ability to build cooperation", "coordination and governance skills", "learning to learn", "giving importance to equality of opportunity, diversity", and " taking into account the needs of society" were revealed (Table 4).

Table 4. Themes, sub-themes and codes related to sustainable leadership behaviors displayed by executives in higher education for lifelong learning.

\begin{tabular}{|c|c|c|c|}
\hline Main Theme & Sub-Theme & Codes & Descriptions \\
\hline \multirow{5}{*}{$\begin{array}{l}\text { Leadership } \\
\text { Behaviors }\end{array}$} & \multirow{5}{*}{$\begin{array}{l}\text { Sustainable } \\
\text { Leadership }\end{array}$} & $\begin{array}{l}\text { Transformational- } \\
\text { transforming } \\
\text { feature }\end{array}$ & $\begin{array}{l}\text { Lifelong learning skills should be transformative to enable the } \\
\text { short-term development of lifelong learning programs in order to } \\
\text { integrate lifelong learning skills into the current academic } \\
\text { curriculum (P10). }\end{array}$ \\
\hline & & Collaboration & $\begin{array}{l}\text { The academic leader needs to have a good ability to connect with } \\
\text { in-house and inter-institutional or non-governmental } \\
\text { organizations (P1). } \\
\text { It would be difficult to talk about a leader who does not produce } \\
\text { projects in collaboration with other organizations (P2). }\end{array}$ \\
\hline & & $\begin{array}{l}\text { Coordination and } \\
\text { governance skills }\end{array}$ & $\begin{array}{l}\text { Coordination and governance skills lifelong learning needs to be } \\
\text { able to functionally manage coordination and governance (P7). }\end{array}$ \\
\hline & & Learner to learn & $\begin{array}{l}\text { Leaders should be those who learn to learn (P5). } \\
\text { It must be a leader open to continuous learning (P8). }\end{array}$ \\
\hline & & $\begin{array}{l}\text { Paying attention } \\
\text { to equality of } \\
\text { opportunity, } \\
\text { diversity and } \\
\text { considering the } \\
\text { needs of the } \\
\text { society }\end{array}$ & $\begin{array}{l}\text { Especially the trainings are given to people who are not educated } \\
\text { for various reasons or should provide equal opportunities to those } \\
\text { who attend such training at certain times due to their work, and } \\
\text { everyone should care about the training slag (P3). } \\
\text { For educators, engineers, or any professional group, they should } \\
\text { have a vision that takes into account the philosophy of learning to } \\
\text { learn (P9). }\end{array}$ \\
\hline
\end{tabular}

The views of the leaders in higher education regarding the leadership behaviors displayed towards lifelong learning have been gathered under a sub-theme of sustainable leadership. Under this sub-theme, the codes "exhibiting transformational-transformative characteristics", "ability to build cooperation", "coordination and governance skills", "learning to learn", "giving importance to equality of opportunity, diversity", and " taking into account the needs of society" were revealed. Similarly, in other studies on sustainable leadership, the key to sustainability in higher education institutions seems to be in line with leadership skills and perspectives. The studies conducted with sustainability reveal that institutions with sustainable leadership have a systematic approach, have collaboration across borders, and problem-solving skills. It underlines that a leader needs to understand the organizational ecosystem to sustain his or her university.

\subsection{Round 2}

Secondly, because the findings on the last question remained superficial, a second interview was conducted with the same administrators with the same questions for more in-depth discussion. In semi-structured face-to-face interviews, interview questions were created using Lambert's theory [33]. At the end of the second interview, it was found to be useful in the process of revealing the research in more detail and analyzing it within the framework of the theory. The obtained results of the second round of interviews are as follows: 
Sustainable leadership behaviors for effective implementation of lifelong learning work, according to administrators in higher education, are increasing staff capacity and cooperation, strategic development, creating long-term goals from short-term goals, benefitting from diversity and the question "how do we learn lessons from the past?".

When the answers to the questions were examined, it was seen that there is support for a sustainable leadership framework for lifelong learning centers. However, when the answers were examined, it was seen that bureaucratic obstacles are at the forefront.

Increasing staff capacity: Lifelong learning administrators in higher education sector believe that increasing staff capacity plays a key role in sustainable leadership. Similarly, it is agreed that the process of improving the effectiveness and efficiency of lifelong learning has gained importance. Some of the points of views of the participants are as follows:

In our lifelong learning center, we organize seminars with the aim of increasing our employees' professional development from time to time. We send them to courses, conferences. On the other hand, as an administrator and a leader who learns lifelong learning, I follow the developments in the world and participate in overseas-based training (P2).

In order to increase the capacity of the staff in our institution, we offer opportunities to motivate and develop the skills of the employees. We support this process, especially through non-governmental organizations or various mentoring practices (P9).

First of all, I can say that I am trying to be an example to my team in order to demonstrate sustainable leadership behaviors for effective implementation of lifelong learning activities. I mean, first of all, I'm constantly renewing myself and learning. In the next phase, my employees and I receive professional training to develop ourselves in an integrated way. From time to time, we increase their motivation with social activities. The more willing and open the atmosphere we provide them, the more efficient the LLP unit becomes and achieves its goal. And thus, we can reap the fruits of sustainable leadership (P4).

Strategic development: According to lifelong learning administrators in higher education, they are pursuing a strategy that involves their stakeholders in the organization in the process of sustainable leadership. A person stated that they could not follow a process that involved their stakeholders because of bureaucratic obstacles, and also another person because of a team that was not specialized.

We keep trying to involve our employees at the lifelong learning unit in the process. We make decisions together, ask for their ideas and try to include them in the process by giving them various tasks. Employees are actively involved in this cycle (P1).

To put it bluntly, we are unable to adequately involve employees in public universities for many reasons, such as bureaucratic obstacles, slow process, working with non-specialists. Since we are not able to make this strategic distribution at the desired level, we experience a coordination disorder in applications with LLP from time to time. Sometimes the fact that you have the goal of being a sustainable leader will not be sufficient alone (P3).

Collaboration: The collaboration, cited by Lambert [33] as the driving force for corporate development, is of great importance. When the answers were examined, collaboration is seen to be implemented and supported, according to the views of the executives of the lifelong learning units in universities. Sample views given are as follows:

As a sustainable leader, I can say that one of the points that make lifelong learning centers more active is collaboration. We are in collaboration with trade unions, NGOs, and similar institutions. In particular, we support employees in terms of creating collaborative work and a common culture. As an example, we have recently collaborated on an issue with an overseas link (P6).

Dreaming of a world where globalization and borders are removed, a strategy of cooperation and networking is inevitable. We are constantly participating in international congresses, seminars, 
workshops. In the name of renewing the institution, we are constantly in pragmatic communication from all disciplines such as social services, law, marketing, etc. I, as the director of the institution, constantly motivate this synergy through mentoring. The staff are more conscious and willing in this sense, and because we are a foundation university, we do not have a shortage of funds, which I would say is a great advantage (P1).

Creating long-term goals from short-term goals: Links to Lambert's framework [33] and the idea of creating long-term goals from short-term goals as a driving force for corporate development. When the answers are examined, creating long-term goals from short-term goals according to the executive views of the lifelong learning units in universities is a process that develops the lifelong learning units of universities. View examples are as follows:

As a lifelong learning center, we set short-term and long-term goals at the beginning of each year with the participation of all personnel. We are evaluating this situation both in terms of curriculum and economic conditions. Thus, we obtain the opportunity to see the development curve (P8).

Creating long-term goals from short-term goals is one of our core strategies as a team. Thanks to this strategy, we can interpret the development and success of the institution. We can say that there can be very comprehensive and intertwined goals, including staff development and executive development. The purpose of these goals is to enhance the ability to taste great achievements from small success and to plan for the future. Thus, we succeed in becoming a sustainable leader and a sustainable institution (P3).

Gaining benefit from diversity: It is the creation of social inclusion and provides integrity for an institution. When the answers were examined, while it may seem difficult to benefit from diversity according to executive opinions in lifelong learning units at public universities, it is a contributing process to benefit from diversity according to executive opinions in lifelong learning units at foundation universities.

As a part of a lifelong learning center, we are collaborating internationally with stakeholders to promote the inclusion of underrepresented groups of all ethnicities and groups. In addition, we include persons with expertise in unifying various disciplines within our staff. In this sense, we are a flexible institution that integrates differences. It's a process that actually feeds us (P7).

I cannot say that we benefit from diversity as an institution. But it's not really up to us to include diversity on the personnel basis. Since this is a state university, this concept is very difficult for us to implement for now, due to bureaucratic obstacles and procedures (P3).

Learning lessons from the past experiences: Learning lessons from the past enables the organization, managers, and leaders to honor past experiences and learn from them to create a better future [22,26,34] and in the education sector, understanding the past is important for understanding the present or the future [23]. When the answers to this question were examined, it was seen that one person gave a positive response, while the others all gave negative responses. They explained the reason for this by linking them to the fact that they had not yet gained experience in their positions, bureaucracy, and lack of expertise. Example views are as follows:

To learn from the past, it takes a long time to work in this position. It takes to understand the purpose and function of this institution. I have to point out that as a manager, I strive to improve the process step by step every day. However, due to the fact that it is already a new institution, there are no lessons yet to be learned from the past. But of course, in order for the lifelong learning center administrator to fully fulfill his role as a sustainable leader, he must use the principle of learning lessons from the past (P10).

I've been working as an administrator at the lifelong learning center for 4 years. It's hard to rebuild an institution and rebuild an organizational culture. Of course, we learn new things every 
year and learn lessons from the past. In a sense, we plan the future according to the lessons we have learned from the past. Not at the desired level, of course. There are many reasons for this: bureaucracy, lack of experts, lack of experience, etc. (P3).

The results of the second round of interview, it was found to be useful in the process of revealing the research in more detail and analyzing it within the framework of the theory. According to lifelong learning administrators in higher education, increasing staff capacity plays a key role in sustainable leadership. According to lifelong learning administrators in higher education, they are pursuing a strategy that involves their stakeholders in the organization in the process of sustainable leadership. One person stated that they could not follow a process that involved their stakeholders because of bureaucratic obstacles, and also another person because of a team that was not specialized. When the answers were examined, creating long-term goals from short-term goals is a process that develops the lifelong learning units of universities, according to the executive views of the lifelong learning units in universities. It is the creation of social inclusion and providing integrity for an institution. When the answers are examined, while it may seem difficult to benefit from diversity according to executive opinions in lifelong learning units at public universities, it is a contributing process to benefit from diversity according to executive opinions in lifelong learning units at foundation universities. When the answers to this question were examined, it was seen that one person gave a positive response, while the others all gave negative responses. They explained the reason for this by linking them to the fact that they had not yet gained experience in their positions, bureaucracy, and lack of expertise.

\section{Conclusions and Recommendations}

In this study, we examine the opinions of higher education managers of lifelong learning centers about their perceptions on Turkey, the strategies they apply, and the difficulties they encounter. It also examines the experiences and views of sustainable leadership practices. As a result of this research, the conclusions and recommendations are as follows:

The results of the first round of interviews, when the views on the meaning of lifelong learning according to the views of the managers working in higher education were examined in the study, it was seen that leaders see lifelong learning as a learning process that contributes to personal development. With this result, it can be said that the high level of perception of lifelong learning leaders regarding lifelong learning is positive. This result is in line with the findings of Doğan and Kavtelek [79]'s study with executives working at the MoNE's lifelong learning institutions. Apart from this study, only one study has been encountered in the literature on the perceptions of lifelong learning managers regarding the concept of lifelong learning. Accordingly, in other studies on lifelong learning, Konokman and Yelken [80] found that instructors have a high level of lifelong learning competence due to the lack of a metaphor to create the perception that lifelong learning competencies are limited. In this context, lifelong learning extends beyond full-time formal education in public institutions. Also, the finding that the executives (leaders) of the institutions have a high level of awareness about lifelong learning is supported. Furthermore, it is understood that the managers of lifelong learning centers are shaped according to the needs of the university by using internal and external connections to strengthen a sustainable lifelong learning center. In addition, as seen in the continuation of the training center, the difficulties of managers in Turkey seem to be a priority, especially economic difficulties. Sustainable leaders identify strategies by looking beyond the short-term gains of higher education institutions. The behaviors exhibited by sustainable leaders are improving the vision of the organization, operationalizing corporate social responsibility, getting top management support, attracting various stakeholders, strengthening and developing stakeholders, communicating with stakeholders, measuring performance, and setting ethical standards [81]. Further, sustainability leadership reflects life awareness [73]. As can be seen, there are many studies conducted with this same result. Also, "exhibiting transformational-transformative characteristics"; Burns et al.'s [74] studies were conducted with this same result. 
From the results of the second round of interviews, according to lifelong learning centers administrators in higher education, increasing staff capacity plays a key role in sustainable leadership. According to administrators in higher education, they are pursuing a strategy that involves their stakeholders in the organization in the process of sustainable leadership.

Collaboration, cited by Lambert [33] as the driving force for corporate development, is of great importance. Also, collaboration is implemented and supported according to the views of the executives of the lifelong learning centers units in universities. Links to Lambert's framework [33] and the idea of creating long-term goals from short-term goals as a driving force for corporate development. Creating long-term goals from short-term goals according to the executive views of the lifelong learning centers units in universities is a process that develops the lifelong learning centers units of universities. When the answers were examined, while it may seem difficult to benefit from diversity according to executive opinions in lifelong learning centers units at public universities, it is a contributing process to benefit from diversity according to executive opinions in lifelong learning centers units at foundation universities. Learning lessons from the past enables the organization, managers, and leaders to honor the past and learn from them to create a better future [11-13,24], and in the education sector, understanding the past is important for understanding the present or the future [12].

As can be seen, in order to effectively implement the limited number of lifelong learning activities according to lifelong learning centers administrators in higher education in Turkey, sustainable leadership behaviors are exhibited and there is a certain awareness. However, administrators at lifelong learning centers at public universities appear to be exposed to more bureaucratic hurdles, lack of experience, and problems with funding, specialization, and flexibility than the administrators at foundation universities. From this point of view, it seems appropriate to take measures to eliminate the deficiencies necessary for lifelong learning administrators in higher education in Turkey to be able to implement lifelong learning activities effectively and to demonstrate sustainable leadership.

As a final word, the lifelong learning process will undoubtedly continue to be an important component of learning, and the role of lifelong learning for sustainable leadership in higher education will become even more important each passing day. Therefore, the recruitment of experts in the field of lifelong learning to the continuing education centers covered in this study is essential for sustainable leadership. In this perspective, the key role played by sustainable leaders in the changing role of universities as learning organizations is essential for a sustainable university. Especially when the flow between developed and developing countries arises, the reasons behind students' lifelong learning will need to be examined through interdisciplinary studies. Therefore, this study should be taken a step further and supported by quantitative research. A quantitative investigation of this study and, in particular, a scale development based on these qualitative findings may be proposed. In addition, it is of importance that sustainable leaders consider and discuss the strategies of universities, put into practice for lifelong learning in a local and global context.

Author Contributions: Conceptualization, G.T.; Methodology, G.T.; Project Administration, G.T. and O.T.; Supervision, O.T. All authors have read and agreed to the published version of the manuscript.

Funding: This research received no external funding.

Acknowledgments: A part of this study was presented as a verbal presentation at the 5th International Conference on Lifelong Education and Leadership for All-ICLEL 2019 held in Baku, Azerbaijan on 9-11 July 2019.

Conflicts of Interest: The authors declare no conflict of interest.

\section{References}

1. Milli Eğitim Bakanlığı (MEB). Türkiye Hayat Boyu Öğrenme Strateji Belgesi ve Eylem Planı 2014-2018; Official Newspaper: Ankara, Turkey, 2014. Available online: http://www.resmigazete.gov.tr/eskiler/2014/07/201407168-1.pdf (accessed on 12 May 2019).

2. Toffler, A. Üçüncü Dalga; Corridor Publishing Çev. Selim Yeniçeri, Koridor Yayıncılık: İstanbul, Turkey, 1980. 
3. Atkin, C. Lifelong learning-Attitudes to Practice in the Rural Context: A Study Using Bourdieu's Perspective of Habitus. Int. J. Lifelong Educ. 2000, 19, 253-265. [CrossRef]

4. Baptiste, I. Beyond Lifelong Learning: A Call to Civically Responsible Change. Int. J. Lifelong Educ. 1999, 18, 94-102. [CrossRef]

5. Boburka, R.R.; Wesp, R.K.; Eshun, S.; Drago, A.L. An Assessment of the Effectiveness of a Classroom Activity Designed to Teach the Value of Lifelong Learning. Stud. Contin. Educ. 2014, 36, 54-66. [CrossRef]

6. Laal, M. Lifelong learning: What does it mean? Procedia-Soc. Behav. Sci. 2011, 28, 470-474. [CrossRef]

7. Milic, S. The Twenty-First Century University and The Concept of Lifelong Learning. Aust. J. Adult Learn. 2013, 53, 151-170.

8. Çalışkan Toyoğlu, A. Okullarda Hayat Boyu Öğrenme Kültürüne İlişkin Öğretmenlerin Alg1 ve Görüşleri. Yayınlanmamış Yüksek Lisan Tezi, Cumhuriyet Üniversitesi, Sivas, Turkey, 2016.

9. Erkal, C. Hayat Boyu Öğrenme Kapsamında Okullar Hayat Olsun Projesi'nin Ilkokullarda Uygulanışının Incelenmesi (Konya Ili Örneği). Yayınlanmmaış Yüksek Lisans Tezi, Necmettin Erbakan Üniversitesi, Eğitim Bilimleri Enstitüsü, Meram/Konya, Turkey, 2015.

10. Günüç, S.; Odabaşı, H.F.; Kuzu, A. Yaşam Boyu Öğrenmeyi Etkileyen Faktörler. Gaziantep Üniversitesi Sosyal Bilimler Dergisi 2012, 11, 309-325.

11. Poyraz, H.; Titrek, O. Türkiye'de Hayat Boyu Öğrenmenin Geliştirilmesi. Abant İzzet Baysal Üniversitesi Ĕ̆itim Fakültesi Dergisi 2013, 131, 115-131.

12. Taşçı, D.; Aydın, C.H.; Kumtepe, E.G.; Kumtepe, A.T.; Kıyık, G.K.; Dinçer, G.D. Eskişehir'de Yaşam Boyu ÖğrenmeBaşlığı Altında Yetişkin Eğitiminin Analizi. Selçuk Üniversitesi Sosyal Bilimler Enstitüsü Dergisi 2015, 34, 197-211.

13. Field, J. Lifelong Learning and The New Educational Order; Trentham Press: Stoke on Trent, UK, 2000.

14. Knapper, C.K.; Cropley, A.J. Lifelong Learning in Higher Education, 3rd ed.; Kogan Page Ltd.: London, UK, 2000.

15. Pollard, A. Learning Through Life-Higher Education and The Life Course of Individuals, in Higher Education and the Life Course; Slowey, M., Watson, D., Eds.; SRHE and Open University Press: Maidenhead, UK, 2003; pp. 167-185.

16. Titrek, O.; Zafer Güneş, D.; Sezen, G. Yükseköğretim ve Yaşam Boyu Öğrenme: Bir Model Önerisi. ICQH 2013. SAU Congress Centre, 12-14 December 2013. Available online: http://www.icqh.net/index.php?page= program (accessed on 17 May 2019).

17. Bayrakçı, M.; Dindar, H. Factors Effecting Students' Lifelong Learning in Higher Education. Int. J. Lifelong Educ. Leadership 2015, 1, 11-20.

18. Farooq, M. Sustainable Leadership Practices in Higher Education Institutions: An Analytical Review of Literature. In Chaos, Complexity and Leadership 2016; Springer Proceedings in Complexity; Erçetin, Ş., Ed.; Springer: Cham, Germany, 2018.

19. Akins, E.E.; Giddens, E.; Glassmeyer, D.; Gruss, A.; Hedden, M.K.; Slinger-Friedman, V.; Weand, M. Sustainability Education and Organizational Change: A Critical Case Study of Barriers and Change Drivers at a Higher Education Institution. Sustainability 2019, 11, 501. [CrossRef]

20. Bottery, M. Leadership, The Logic of Sufficiency and the Sustainability of Education. Educ. Manag. Adm. Leadersh. 2012, 40, 449-463. [CrossRef]

21. Cortese, A.D. The Sustainable University: Green Goals and New Challenges for Higher Education Leaders; James Martin, James Samels \& Associates, Education for Sustainability Second Nature; Johns Hopkins University Press: Baltimore, MD, USA, 2012; pp. 17-31.

22. Davies, B. The Essentials of School Leadership; Sage: London, UK, 2009.

23. Fullen, M. Leadership and Sustainability; Corwin Press: Thousand Oaks, CA, USA, 2005.

24. Hargreaves, A.; Fink, D. The Seven Principles of Sustainable Leadership. 2003. Available online: http: //jotamac.typepad.com/jotamacs_weblog/files/seven_principles.pdf (accessed on 18 May 2019).

25. Hargreaves, A. Sustainable Leadership \& Development in Education: Creating the Future, Conserving thePast. Eur. J. Educ. 2007, 42, 1-43.

26. Hargreaves, A.; Fink, D. Energizing Leadership for Sustainability. In Developing Sustainable Leadership; Davies, B., Ed.; Paul Chapman Publishing: London, UK, 2007.

27. Hargreaves, A. Sustainable Leadership. In The Essentials of School Leadership; Davies, B., Ed.; Sage: Thousand Oaks, CA, USA, 2009; pp. 183-200. 
28. Hoyle, E.; Wallace, M. Educational Leadership: Ambiguity, Professionals, and Managerialism; Sage: London, UK, 2005.

29. Segovia-Pérez, M.; Laguna-Sánchez, P.; de la Fuente-Cabrero, C. Education for Sustainable Leadership: Fostering Women's Empowerment at the University Level. Sustainability 2019, 11, 5555. [CrossRef]

30. EAUC. Sustainability: Key to Long-term Institutional Success, A Guide for Members of Governing Bodies. 2018. Available online: https://www.iau-hesd.net/sites/default/files/documents/a5_eauc_booklet_final.pdf (accessed on 28 May 2019).

31. Farooq, M.; Othman, A.; Nordin, M.S.; Ibrahim, M.B. Analysing the Relationship between Sustainable Leadership, Talent Management and Organization Health as Predictors of University Transformation. J. Posit. Manag. 2017, 8, 32-50. [CrossRef]

32. Greig, A.; Priddle, J. Mapping Students' Development in Response to Sustainability Education: A Conceptual Model. Sustainability 2019, 11, 4324. [CrossRef]

33. Lambert, S. Sustainable Leadership and the Implication for the General Further Education College Sector. J. Furth. High. Educ. 2011, 35, 131-148. [CrossRef]

34. Lambert, S. The Perception and Implementation of Sustainability Leadership Strategies in Further Education Colleges. J. Leadersh. Educ. 2012, 11, 102-119. [CrossRef]

35. Šimanskienė, L.; Župerkienè, E. Sustainable Leadership: The New Challenge for Organizations. Forum Sci. Oeconomia 2014, 2, 81-93.

36. Quinn, L.; Dalton, M. Leading for Sustainability: Implementing the Tasks of Leadership. Corparate Gov. 2009, 9, 21-38. [CrossRef]

37. Svensson, G.; Wood, G. Sustainable Components of Leadership Effectiveness in Organizational Performance. J. Manag. Dev. 2006, 25, 522534. [CrossRef]

38. Khan, M.I. Sustainability and Higher Education Leadership; Higher Education Leadership Lens, Suny Sail Institute: Albany, NY, USA, 2018. Available online: https://sunysail.org/2018/12/19/sustainability-and-highereducation-leadership/ (accessed on 18 August 2019).

39. Bora, A. Forecasting RTU Enrollees Through Time Series Approach. J. Int. Acad. Res. Multidiscip. 2014, 2, 234-240.

40. Smith, A. Integrating Lifelong Learning Perspectives. In The Eu Memorandum on Lifelong Learning; Medel-Añonuevo, C., Ed.; UNESCO Institute for Education: Hamburg, Germany, 2002; p. 47.

41. Stromquist, N.P.; Lozano, G. Scratching the Surface: The Hidden Functions and Contributions of Popular Universities. In Handbook of Adult and Lifelong Education and Learning. Basingstoke; Holford, J., Jarvis, P., Milana, M., Waller, R., Webb, S., Eds.; Palgrave McMillan: London, UK, 2017.

42. Toprak, M.; ve Erdoğan, A. Yaşam boyu öğrenme: Kavram, Politika, Araçlar ve Aygulama. Yükseköğretim ve Bilim Dergisi 2012, 2, 69-91.

43. Collins English Dictionary. HarperCollins Publishers: Glasgow, UK. Available online: https://www. collinsdictionary.com/dictionary/english/lifelong-learning (accessed on 17 May 2019).

44. Day, C. Developing Teachers the Challenges of Lifelong Learning; Bristol Taylor \& Francis Inc.: Bristol, UK, 1999.

45. Önal, İ. Tarihsel Değişim Sürecinde Yaşam Boyu Öğrenme ve Okuryazarlık: Türkiye Deneyimi. Bilgi Dünyası 2010, 11, 101-121.

46. Loads, D. Effective Learning Advisers' Perceptions of Their Role in Supporting Lifelong Learning. Teach. High. Educ. 2007, 2, 235-245. [CrossRef]

47. Atali, Z. A Brief History of the Future; Archipelago: New York, NY, USA, 2010.

48. Aksoy, M. Kavram Olarak Hayat Boyu Öğrenme ve Hayat Boyu Öğrenmenin Avrupa Birliği Serüveni. Bilig Dergisi 2013, 24, 23-48.

49. Oskay, Ö.; Erdem, E.; Akkoyunlu, B.; Soran, H.; Yılmaz, A. Öğretmenlerin Öğretme ve Öğrenme Sürecindeki Yeterlikler Açısından Kendilerini Değerlendirmeleri Üzerine Bir Çalışma.Uluslararası Öğretmen Yetiştirme Politikaları ve Sorunları Sempozyumu II. Bildiriler Kitabı; Hacettepe Üniversitesi Eğitim Fakültesi: Ankara, Turkey, 2010; pp. 211-221.

50. Chapman, J.; Aspin, D. Schools and the Learning Community: Laying the Basis for Learning Across the Lifespan. In International Handbook on Lifelong Learning; Aspin, D., Chapman, J., Hatton, M., Sawono, Y., Eds.; Kluwer Press International: Dordecht, The Netherlands, 1999.

51. Erdamar, G.K. Yaşam Boyu Öğrenme. Ĕ̆itimde Yeni Yönelimler; Özcan, D., 4.Baskı, Eds.; Pegem Yayıncılık: Ankara, Turkey, 2010. 
52. Şirin, A. Halk Eğitim Merkezlerinin Sanat Eğitimi Bağlamında Yetişkin Eğitimindeki Yeri ve Önemi. Master's Thesis, Selçuk Üniversitesi Yüksek Lisans Tezi, Konya, Turkey, 2008.

53. MEB. Milli Ĕ̆itim Bakanlığının Teşkilat ve Görevleri Hakkında Kanun Hükmünde Kararname; Official Newspaper: Ankara, Turkey, 2011. Available online: https://www.resmigazete.gov.tr/eskiler/2011/09/20110914-1.htm (accessed on 14 September 2019).

54. Akçay, R.C.; Yıldırım, R. Evaluating the continuing education centers in terms of life long learning. In Proceedings of the Procedia-Social and Behavioral Sciences, 5th World Conference on Educational Sciences-WCES 2013, Rome, Italy, 5-8 February 2013; Elsevier Ltd.: Amsterdam, The Netherlands, 2014; pp. 1756-1762.

55. YÖK. Türkiye'nin Yükseköğretim Stratejisi. 2007. Available online: https://www.yok.gov.tr/Documents/ Yayinlar/Yayinlarimiz/Turkiyenin-yuksekogretim-stratejisi.pdf (accessed on 17 September 2019).

56. Müller, R.; Remdisch, S.; Köhler, K.; Marr, L.; Repo, S.; Yndigegn, C. Easing Access for Lifelong Learners: A Comparison of European Models for University Lifelong Learning. Int. J. Lifelong Educ. 2015, 34, 530-550. [CrossRef]

57. Rienzo, P. Recognition and Validation of Non-Formal and Informal Learning: Lifelong Learning and University in the Italian Context. J. Adult Contin. Educ. 2014, 20, 39-52. [CrossRef]

58. İmanov, V. Üniversitelerdeki Uygulama ve Araştırma Merkezleri: Genel Manzara, Modeller ve Sorunlar. Uluslararası Yükseköğretim Kongresi: Yeni Yönelişler ve Sorunlar (UYK-2011) Bildiri Kitabı; Deomed Yayıncılık: İstanbul, Turkey, 2011; pp. 805-813. Available online: www.uyk2011.org (accessed on 21 September 2019).

59. Yıldırım, R. Üniversitelerdeki Yaşam Boyu Öğrenme Hizmetlerinin Yönetsel Etkililiğinin Değerlendirilmesi (Yayınlanmış Doktora Tezi); Çanakkale Onsekiz Mart Üniversitesi Eğitim Bilimleri Enstitüsü: Çanakkale, Turkey, 2017.

60. Devlin, M. Effective University Leadership and Management of Learning and Teaching in a Widening Participation Context: Findings from Two National Australian Studies. Tert. Educ. Manag. 2013, 19, $233-245$. [CrossRef]

61. Yukl, G.; Van Fleet, D.D. Theory and Research on Leadership in Organizations. In Handbook of Industrial E Organizational Psychology, 2nd ed.; Dunnette, M.D., Hough, L.M., Eds.; Consulting Psychologists Press: Palo Alto, CA, USA, 1990; p. 3.

62. Hughes, R.L.; Ginnett, R.C.; Curphy, G.J. Leadership: Enhancing the Lessons of Experience, 4th ed.; McGraw-Hill Irwin: Boston, MA, USA, 2002.

63. Buluç, B. Bilgi Çağı ve Örgütsel Liderlik. Yeni Türkiye 21. yy. Özel Sayısı. Spec. Number 1998, 20, 1-13.

64. Bennis, W.; Nanus, B. Leaders: The Strategies for Taking Charge; Harper \& Row: New York, NY, USA, 1985.

65. McClelland, D.C. Power: The Inner Experience; Irvington Press: Irvington, NY, USA, 1975.

66. Bass, B.M. Bass and Stodgill's Handbook of Leadership; Free Press: New York, NY, USA, 1998.

67. Kelly, R. The Power of Followership: How to Create Leaders People Want to Follow and Followers Who Lead Themselves; Doubleday Currency: New York, NY, USA, 1992.

68. Goffee, R.; Jones, G. Why Should Anyone Be Led by You? Harv. Bus. Rev. 2000, 63-70.

69. Hogan, R.; Hogan, J. Assessing Leadership: A View from the Dark Side. Int. J. Sel. Dev. 2001, 9, 40-51. [CrossRef]

70. Sze'Kely, F.; Knirsch, M. Responsible Leadership and Corporate Social Responsibility. Eur. Manag. J. 2005, 23, 628-647. [CrossRef]

71. Middlebrooks, A.; Miltenberger, L.; Tweedy, J.; Newman, G.; Follman, J. Developing a Sustainability Ethic in Leaders. J. Leadersh. Stud. 2009, 3, 31-43. [CrossRef]

72. Pelinescu, E.; Rădulescu, M. New Times, New Economy a Newborn Leader: The Eco-Leader. Hyperion Int. J. Econophys. New Econ. 2011, 4, 81-94.

73. Ferdig, M.A. Sustainability Leadership: Co-Creating a Sustainable Future. J. Chang. Manag. 2007, 7, $25-35$. [CrossRef]

74. Burns, H.; Diamond-Vaught, H.; Bauman, C. Leadership for Sustainability: Theoretical Foundations and Pedagogical Practices that Foster Change. Int. J. Leadersh. Stud. 2015, 9, 88-100.

75. Christensen, L.B.; Johnson, R.B.; Turner, L.A. Research Methods Design and Analysis; Pearson: Cambridge, UK, 2015.

76. Patton, M.Q. Qualitative Research Evaluation Methods; Sage: Thousand Oaks, CA, USA, 2002.

77. Yıldırım, A.; Şimşek, H. Sosyal Bilimlerde Nitel Araştırma Yöntemleri; Seçkin Yayınları: Ankara, Turkey, 2013. 
78. Miles, M.; Huberman, A.M. An Expanded Sourcebook Qualitative Data Analysis; Sage Publications: Thousand Oaks, CA, USA, 1994.

79. Doğan, S.; Kavtelek, C. Hayat Boyu Öğrenme Kurum Yöneticilerinin Hayat Boyu Öğrenmeye Ilişkin Algıları. Abant İzzet Baysal Üniversitesi Ĕ̆itim Fakültesi Dergisi 2015, 15, 82-104.

80. Konokman, G.Y.; Yelken, T.Y. Eğitim Fakültesi Öğretim Elemanlarının Yaşam Boyu Öğrenme Yeterliklerine İlişkin Algıları. Hacettepe Üniversitesi Eğitim Fakültesi Dergisi 2014, 29, $267-281$.

81. D'Amato, A.; Roome, N. Toward an Integrated Model of Leadership for Corporate Responsibility and Sustainable Development: A Process Model of Corporate Responsibility Beyond Management Innovation. Corp. Gov. Int. J. Bus. Soc. 2009, 9, 421-434.

(C) 2019 by the authors. Licensee MDPI, Basel, Switzerland. This article is an open access article distributed under the terms and conditions of the Creative Commons Attribution (CC BY) license (http://creativecommons.org/licenses/by/4.0/). 